\title{
Location, Ownership, Origin and the Spillover-Productivity Nexus. Evidence from Uganda Manufacturing Firms
}

\author{
John Mayanja Bbale ${ }^{1} \&$ John Bosco Nnyanzi ${ }^{2}$ \\ ${ }^{1}$ Department of Policy and Development Economics, Makere re University, Kampala, Uganda \\ ${ }^{2}$ Department of Econo mic Theory and Analysis, Makerere University Kampala, Uganda \\ Correspondence: John Bosco Nnyanzi, Department of Economic Theory and Analysis, Makerere University \\ Kampala, Uganda. E-mail: jbnnyanzi@yahoo.com
}

\author{
Received: June 13, 2016 Accepted: June 27, 2016 Online Published: July 30, 2016 \\ doi:10.5539/jsd.v9n4p 198 \\ URL: http://d x.doi.org/10.5539/jsd.v9n4p 198
}

\begin{abstract}
The main purpose of this article is to investigate the drivers of labor productivity in the firms at the intra-industry level with focus on the spillover effects of FDI. Using a fixed effects approach, we estimate an expanded Cobb-Douglas production function in its intensive form to isolate the effects of increased capital intensity on labor productivity as well as the spillovers, using annual Private Sector Investment Survey data collected on the Ugandan manufacturing firms over the period 2007-2010. Over all, there are significant negative horizontal spillovers for the domestic firms in Uganda, with OECD-originating FDI appearing to be the main source of such effects. By location, these are most adverse in the western and eastern regions and better spillo vers can be traced in the central region. Additional findings point to firm size, labor quality and profit as positive contributors to labor productivity, whereas technology gap exhibits a detrimental impact just as we document no significant effect of capital intensity. Larger domestic firms appear to benefit significantly from spillovers in industries where foreign firms have a larger presence. The aforementioned findings reflect the need for well-designed policies to improve the competitiveness of local firms particularly via an incentive-equal opportunity-policy that captures both domestic and foreign investors and to improve in frastructure and other investor-friendly environment in the East and Western parts of Uganda. Similarly, our results suggest that the promotion of joint ventures (foreign) is likely to generate unequivocal benefits to the manufacturing sector in Uganda not only in terms of less negative horizontal spillovers but also from the labor quality, firm size and profit spillovers perspective. Finally, the finding of learning difficulties of domestic firms from foreign firms calls for programs in line with skill acquisition through job training and the review of the curriculum to focus on labor quality.
\end{abstract}

Keywords: foreign direct investment, horizontal spillovers, manufacturing firms, labor productivity, Uganda, OECD

\section{Introduction}

Foreign direct investment (FDI) is becoming a very important source of foreign capital for many economies. On this basis, many African countries have embraced polic ies to provide a friendly environment for foreign investment, sometimes at the expense of domestic investment. For example, the removal or relaxation of FDI restrictions and the provision of foreigners with incentive packages in the form of subsidies on in frastructure, lower taxes, tax holidays, free land, and import duty exemptions inter alia. The justification often advanced for such policies hinges on the argument that FDI assists human capital formation, improves management skills, contributes to international trade integration, helps create a more competitive business environment, enhances enterprise development and employ ment creation. While an opposite phenomenon is equally likely, particularly in terms of the crowding-out effect, perusal in the available records seems to suggest that these policies might be instrumental not only in catalyzing economic growth, which is the most potent tool for poverty alleviation (Blomström et al., 2000) but more so in accelerating FDI inflows to developing countries if any development so far is to be sustainable. According to the UNCTAD (2015), inward FDI flows to developing economies in 2014 reached their highest level at $\$ 681$ billion with a $2 \%$ rise, reflecting an extended lead in global inflows. For Sub-Saharan Africa in particular, an increase of $5 \%$ to $\$ 42$ billion is recorded while the entire Africa is said to have contributed a meager $3 \%$ of the world FDI inflows in 2007, but which shot to 5.3\% in 2010. Elsewhere, 
The State of East Africa 2013 report identifies Uganda and Tanzania to have attracted the most FDI in 2012 in the East African region. Net FDI inflows to Uganda in particular increased on average from $\$ 90.64 \mathrm{M}$ to $\$ 242.71 \mathrm{M}$ in the periods 1991- 2000 and 2001-2005, respectively, reflecting a 168\% increase. For the year 2006 and 2009 , an increase of $24 \%$ from $\$ 644.26 \mathrm{M}$ to $\$ 798.77 \mathrm{M}$ is recorded (UNCTAD, 2010). Interestingly, a previous study by the World Bank (2004) found Uganda to be 60\% and 40\% less than Kenya and Tanzania respectively in labor productivity. Mindful of such findings, in the current study we investigate whether or not domestic firms in Uganda benefit from the observed inflows of foreign investment particularly in the manufacturing sector and the relevant channels via which these spillovers could be reaped.

According to Blomström et al. (2000), FDI to developing countries might trigger technology spillovers to low technology domestic firms. A related argument had earlier on been advanced in a seminal work by Aitken and Harrison (1999) who points out that domestic firms could gain from foreign firms via accelerated diffusion of new technology once foreign firms introduce new products or processes to the domestic market. On the other hand, by simply observing nearby foreign firms or when domestic employees move from foreign to domestic firms, domestic firms could increase their productivity through technology diffusion. These arguments notwithstanding, the presence of foreign firms may also lead to negative spillover effects on the host-country firms. For example, the latter may not be able to compete favorably with foreign firms in the labor markets and as a result, there is likely to be increased mobility of skilled workers from domestic to foreign firms under the assumption that foreign firms pay more than domestic firms. In addition, as indicated by Aitken and Harrison (1999), entry of foreign firms is likely to disturb the existing market equilibrium in the host country thereby forcing domestic firms to produce less output and increase their average costs. Failure to meet these costs may force some domestic firms to exit production and in the long run productivity will be reduced. It is therefore not illogical to hypothesize that competition may result into reduced market shares, increased poaching of bes $t$ workers from domestic firms and making access to credit more difficult for domestic firms because foreign investors may be lower-risk borrowers compared to their local competitors. The latter scenario may force domestic firms to produce less output.

Given the two opposing theoretical justifications above, economists and other scholars still grapple with the puzzle regarding the role of Multi-national corporations (MNCs) in local firms. In the current paper we are interested in the contribution of FDI to the productivity of domestic manufacturing firms in Uganda. The choice for the manufacturing sector is precipitated by a reasonable argument that the industry has the potential to be a driving force and cornerstone for Uganda's modernization and job creation. Yet its share in aggregate output has consistently remained low despite the macroeconomic and industrial policies to improve its competitiveness. At the same time, both foreign and domestic firms have registered tremendous increase at least in number (U BOS, 2014). Perhaps one would expect to observe a sizeable contribution of the manufacturing sector as domestic firms accelerate production, improve productivity and efficiency by probably learning from foreign firms and gaining from technological diffusion. One vital fact however is that the manufacturing sector in Uganda, well-known to be dominated by s mall and medium enterprises (SMEs), is still largely engaged in the production of low value added goods, comprising basic consumer goods, processed foods, tobacco and beverages, non-metallic minerals and metallic fabrication, wood and wood products, chemicals and chemical products, leather and footwear, textile and wearing apparels, and sawmilling, printing, and publishing. Heavy investments by foreign companies are more pronounced in textiles, steel mills, tanneries, bottling and brewing, and cement production, (African Development Bank (AfDB), 2014). Production has been growing in varying degrees from year to year, as more and more domestic and MNCs continue to join the sector. For example, evidence from UBOS (2014) shows that overall, the index of production for manufacturing for the year 2013 was 199.5 demonstrating a 3.2\% increase compared to the year ending 2012. Growth was highest in 'Food Processing' with $10.5 \%$ growth, followed by 'Saw Milling' (8.4\%), 'Metal Products' (6.2\%) and 'Bricks and Cement' (5.0\%) while other industry groups combined recorded a positive rise of $5.7 \%$. Subsectors whose output reduced less than zero since the year, 2005 were 'Drinks and Tobacco' $(-2.0 \%)$, 'Chemicals; and foam products' $(-0.2)$ and Textiles (27.7). Specifically, Textiles, Clothing and Footwear dropped by 27.7\%as shown in Table 1. 
Table 1. Index of Production 2005-2013

\begin{tabular}{lcccccccccccc}
\hline Industry Group & $\mathrm{W}$ & 2005 & 2006 & 2007 & 2008 & 2009 & 2010 & 2011 & 2012 & 2013 & $\%$ change, \\
& & & & & & & & & & & 2013 \\
\hline Total manufacturing & 1000 & 125.8 & 129.6 & 145.2 & 156.4 & 173.9 & 180.8 & 186.7 & 193.4 & 199.5 & 3.2 \\
Food processing & 400 & 110 & 117 & 126 & 139 & 162 & 153.5 & 145.4 & 158.4 & 175.1 & 10.5 \\
Drinks and Tobacco & 201 & 146 & 146 & 180 & 193 & 196 & 211.7 & 251.5 & 266.4 & 261.0 & -2.0 \\
Textiles, clothing and & 43 & 165 & 135 & 163 & 142 & 187 & 182.7 & 188.4 & 192.1 & 138.8 & -27.7 \\
foot wear & & & & & & & & & & & \\
Sawmilling, paper and & 35 & 125 & 132 & 149 & 168 & 210 & 216.2 & 212.4 & 234.4 & 254.0 & 8.4 \\
printing & & & & & & & & & & & \\
Chemicals, paints, soap & 97 & 130 & 132 & 145 & 167 & 22 & 245.6 & 218.9 & 209.3 & 208.8 & -0.2 \\
and foam Products & & & & & & & & & & & \\
Brick and cement & 75 & 126 & 149 & 156 & 173 & 166 & 209.3 & 244.4 & 239.9 & 252.0 & 5.0 \\
Metal products & 83 & 125 & 132 & 140 & 130 & 124 & 139.1 & 150.7 & 140.0 & 148.7 & 6.2 \\
Miscellaneous & 66 & 130 & 121 & 138 & 152 & 152 & 157.6 & 157.3 & 152.7 & 161.3 & 5.7 \\
\hline
\end{tabular}

Source: Uganda Bureau of Statistics, various abstracts

The yet unanswered question however is whether the presence of foreign firms has had any significant impact on the production capacity of domestic firms as the manufacturing sector in Uganda continues to exhibit gro wth in average production. The current paper bridges the gap by examining the impact of FDI on labor productivity over the period 2007- 2010, a period that coincides with significant FDI inflows particularly in the manufacturing sector. The relevance of our investigation is not unambiguous. Scanty literature exists in this area with a few focusing mainly on investigating the determinants of FDI and impact on economic growth (e.g. Obwona, 2001) while others that link FDI spillovers to domestic firms in the LDCs have used macro data (e.g. Karbasi et al., 2000; and, Mutenyo et al., 2008). The results from the latter strand of literature might obscure individual firm characteristics and lead to irrelevant policies. To overco me this problem, other studies use mic ro level data to analyze individual countries (e.g. Gorg and Strobl, 2005; Annika, 2006; Galeotti, 2009; and, Waldkirch and Ofosu, 2010). The underlying argument for a micro approach is that the conclusions are dependent on the particular country under analysis. To our knowledge, no similar analysis using firm-level data has been done for the case of Uganda. In addition to the scarcity of literature, the existing empirical evidence on such spillover effects from FDI is to-date mixed and ambiguous. While some studies document significant and positive spillovers from FDI (e.g. Javorcik, 2004; and, Nguyen 2008), others register a negative effect (e.g. Konings, 2001; Blomströmet al. 2000; De Backer and Sleuwaegen, 2003; and, Bwalya, 2006). Moreover it is also equally not uncommon to find records of no significant spillover effects from foreign firms on domestic firms (e.g. Kathuria, 2001; and, Mebratie and Bedi, 2013).

In light of these considerations, our contribution to the existing literature hinges on the an alysis of FDI spillovers on Ugandan manufacturing firms. For, the co-existence of domestic and foreign firms is an unquestionable phenomenon in this region and Uganda in particular. Specifically, we focus on three main questions: First, what drives labor productivity in the manufacturing firms in Uganda? Does foreign presence matter? Second, which subsectors benefit more than others in the presence of foreign firms? Finally, does the origin of foreign investment, the geographical location in the recipient country and ownership influence the nature of spillovers to domestic firms? The essence of the last multifaceted objective is to trace the impact of heterogeneity of FDI inflows on domestic firms in Uganda via spillovers. It needs not to be overemphasized that the origin of the foreign firms in Uganda is multifold; while some come from the Organization for Economic Co-operation and Develop ment (OECD) countries, the others are from Asia and other African countries (see Table 2 below). Given the increasing presence of Asian countries, and China in particular, in Africa, we wish to establish the nature of spillovers drawn from each source. The focus is on the role of OECD countries vis -à-vis other prominent but growing sources of inward FDI to Uganda, viz. Asia and Africa. Similarly, we uncover the impact of the 'geography of spillovers' within the host country. 
Table 2. Manufacturing sector in Uganda by ownership, location and origin of foreign investors

\begin{tabular}{lcccccccc}
\hline & Central & East & West & OECD & Asia & Africa & $\begin{array}{c}\text { Central } \\
\text { America }\end{array}$ & Uganda \\
\hline Joint Venture & 52 & 4 & 0 & 24 & 16 & 16 & 0 & 0 \\
$\%$ & 92.86 & 7.14 & 0 & 42.86 & 28.57 & 28.57 & 0 & 0 \\
Joint Venture Foreign & 108 & 12 & 8 & 36 & 40 & 52 & 0 & 0 \\
$\%$ & 84.38 & 9.38 & 6.25 & 28.13 & 31.25 & 40.63 & 0 & 0 \\
Joint Venture Local & 80 & 16 & 0 & 4 & 0 & 0 & 0 & 92 \\
$\%$ & 83.33 & 16.67 & 0 & 4.17 & 0 & 0 & 0 & 95.83 \\
Wholly Foreign & 152 & 36 & 4 & 64 & 48 & 72 & 4 & 0 \\
$\%$ & 79.17 & 18.75 & 2.08 & 34.04 & 25.53 & 38.3 & 2.13 & 0 \\
Wholly Local & 472 & 20 & 40 & 8 & 0 & 0 & 0 & 524 \\
$\%$ & 88.72 & 3.76 & 7.52 & 1.5 & 0 & 0 & 0 & 98.5 \\
\hline Total & 864 & 88 & 52 & 136 & 104 & 140 & 4 & 616 \\
\hline
\end{tabular}

Source: Author calculations based on Private Sector Investment Survey

The results from our study suggest an existence of negative horizontal spillovers. While firms located in the central region experience greater spillovers in relation to others in the east or western parts of Uganda, the foreign investors originating from OECD countries have a remarkably better contribution in terms of spillovers to the Ugandan domestic manufacturing firms in comparis on to those sourced from Asia or other parts of Africa. Additional evidence exhibits larger technology gaps as detrimental to labor productivity while the opposite holds for profit and labor quality. Incidentally, we fail to find significant evidence of the role of capital intensity in the facilitation of the employee productivity.

The rest of the paper is organized as follows: While in Sections 1 and 2 we present the introduction and a review of the relevant literature respectively, Section 3 bears an explanation of the methodology and data. The results and discussion are then covered in Section 4, while we provide the summary and concluding remarks in Section 5 .

\section{Literature Review}

According to theory, there are two effects of FDI, namely: the direct and indirect effects. Directly, FDI could increase employment opportunities, capital accumulation, international markets through exports, usage of advanced equipment and technology (Blomström et al. 2000). The indirect effects of FDI are spread through specific contacts between foreign firms and domestic firms. When MNCs penetrate new markets, they always protect themselves against their domestic competitors by preventing technology leakages and other spillovers from taking place. The protection channels include inter alia intellectual property rights, paying higher wages to prevent the movement of labor from one firm to another and moving to countries that cannot imitate their proprietary assets. However despite these measures, some indirect effects are diffused to their domestic competitors. In the current study, we focus on the indirect effects of FDI associated with technology spillovers from MNCs to manufacturing firms. Domestic firms may indirectly benefit from the presence of foreign firms in a country through both vertical (inter-industry) and horizontal (intra-industry) spillovers. The vertical spillovers are known to occur as a result of the interaction between foreign and domestic firms not in the same industry. On the other hand, domestic firms are likely to benefit from the horizontal spillovers that work mainly among firms within the same industries through three distinct theoretical channels. The first channel is where technology diffuses to domestic firms of the hosting countries through demonstration and imitation effects. This takes place when domestic firms observe the actions of foreign firms, learn about new technologies which they can apply locally and implement the techniques to increase domestic productivity (Aitken et al. 1997). In fact after observing the product innovation from MNCs, domestic firms may learn the successes and failures of foreign firms which may help them to increase their productivity. The second chan nel is the competition effect that is also related to the demonstration effect but helps domestic firms to maintain their market shares by improving the product quality and may encourage them to operate more efficiently and adopt new technologies than it would have been the case without MNCs (Bitzer and Gorg, 2008). However, if the competition effects dominate, 
the effects of FDI on domestic firms could be negative. Aitken and Harrison (1999) argues that, the presence of FDI in a host country destabilizes the market equilibrium forcing domestic firms to produce less output and reduce their market shares. In addition, competition may also force domestic firms to reduce their production below optimal levels and this increases the prices of their products. The third channel is that of the labor turnover or mobility effects where by workers and managers who received training and were originally employed by the foreign firms may either move to domestic firms with their acquired skills from foreign firms or establish their own businesses in similar fields taking with them their upgraded human capital which thus becomes available to domestic firms, raising their measured productivity. Moreover, as argued in Haddad and Harrison (1993), the scope of technology diffusion and transfer depends on the absorptive capability of domestic firms. Intuitively, an increase in the difference in technological complexity between foreign and domestic firms theoretically discourages any gain from spillovers by domestic firms.

In light of the above theoretical underpinnings, there is a continued debate concerning the direct and indirect effects of FDI on domestic firms. Several empirical studies have addressed the issue but the findings are overly inconclusive and characterized by a mixture of evidence. A study by Javorcik (2004) for example looks for both horizontal and vertical spillovers using firm-level panel data and finds that total factor productivity (TFP) of Lithuanian firms is positively correlated with the extent of potential contacts with MNC customers in downstream sectors. The author indicates that a one standard deviation increase in foreign presence in the buying sectors is associated with a 15\% increase in the productivity of firms in the supplying industry. The observation of the positive productivity effects however is only valid for joint ventures and not the fully owned foreign affiliates. Relatedly, Marcella and Resmini (2010) investigate both the horizontal and vertical spillovers in Bulgaria, Poland and Romania and document a positive relationship between FDI and the domestic firms but conditional on the absorptive capacity and technological levels of the host country. Similarly, Nguyen (2008) examines the effects of FDI on the domestic productivity in Vietnamese manufacturing industries through horizontal and vertical linkages and records positive spillover effects from FDI through both horizontal and backward linkages. In addition, the study notes that the Vietnamese regions benefit from FDI spillovers but these spillovers differ from region to region; and that the private firms have strong linkages through technical assistance and technology transfer with foreign invested firms while the lin kages of state owned enterprises with foreign invested firms are very weak. Domestic firms with higher human capital stock, better financial development and lower technology gap are found to experience positive effects from FDI resulting into increased productivity. On his part, Bwalya (2006) examines the productivity spillovers from foreign firms to domestic firms using firm level data for manufacturing firms in Zambia employing a Cobb-Douglas production function. The GMM estimation results therefrom indicate that the productivity of domestic firms reduces as foreign presence in the sector increases which the author attributes to adverse competition effects of inward FDI.

On the other hand, an adverse effect of foreign presence on domestic firm productivity is not uncommon in empirical literature. For example, Waldkirch and Ofosu (2010) examine the foreign presence, spillovers and productivity in Ghanaian manufacturing firms and find that foreign presence in the manufacturing sector has a negative effect on the labor productivity of domestically owned firms. The authors argue that domestic firms experience negative effects (intra-industry effect) because foreign firms in Ghana not only get incentives but also face a lower marginal cost which allows them to compete more successfully in product and factor markets and attract more skilled workers from the domestic firms. They argue that while competitive pressures in the long run may induce efficiency through knowledge spillovers, in the short run FDI inflows may be associated with negative consequences for domestic firms. Likewise, Ping et al. (2009) use a large panel data set covering all manufacturing firms in China over the period 1998-2005 to examine whether there are some productivity spillovers from FDI to domestic firms. In estimating the productivity, they control for a possible simultaneity bias using semi-parametric estimation techniques and find that Hong Kong, Macao and Taiwan (HMT) invested firms generate negative horizontal spillovers while Non-HMT foreign invested firms (mostly from OECD countries) are associated with positive horizontal spillovers in China. However these two opposing horizontal effects cancel out at the aggregate level. Similarly, a study by Galeotti (2009) on the Czech Republic, using panel data over the period 1990-2006, confirms the evidence that foreign direct investors produce negative spillovers on domestic firms. The findings reveal that these spillovers do not play a dominant role for the performance of privatized do mestic firms in the glass sector and the importance of taking into account the indust rial sector in the study of spillovers. However, additional findings support the importance of geographic proximity and the agglomeration of foreign direct investors as a channel of spillovers.

A recent study by Mebratie and Bedi (2013) however investigates the relationship between FDI and labor productivity of domestic firms in South Africa using two-period (2003 and 2007) firm level panel data and find 
no spillover of foreign firms on labor productivity. Similar findings are recorded in Chang-Tai (2006) who, using a unique plant-level panel dataset from the Chinese manufacturing sector to measure the effects of foreign firms on the productivity of domestic firms, reveals that foreign firms are more productive than domestic firms in the same industry but that there are no spill-over effects from foreign to domestic firms. Support for such an outcome can also be traced in Ruane and Ugur (2004) who investigate the spillover effects of FDI on the labor productivity levels of domestic firms in the Irish manufacturing sector for the period 1991-1997. Controlling for capital intensity and labor quality of these plants, they find no evidence of significant productivity spillovers from FDI. Gorodnichenko et al. (2007) reiterates similar findings in their analysis of the spillovers in 17 emerg ing countries and find no horizontal spillovers, except for older firms and firms in the service sector. Indeed Annika (2006) evaluates the relationship between FDI and Indian pharmaceutical industry and reveals that there is no correlation between FDI and productivity in domestic firms because of the "absorptive capability".

In some other literature however, the results are dependent on the country under analysis. For example in Vahter (2004) while FDI is negatively related to domestic productivity in Estonia, it is positively related in Slovenia. Moreover, the effects appear to be dependent on the conditions in the recipient countries such as types of ownership (jo int venture or fully foreign owned) and the level of skilled labor. Gorg and Strobl (2005) look at the issue of ownership but from a different perspective. The authors employ Ghanaian data to investigate whether or not the owner of a domestic firm had previous experience with a foreign firm which they relate to firm-level productivity. Their study findings suggest that firms run by the owners who worked for foreign firms in the same industry before opening up their own firms, are more productive compared to other domestic firms that did not have contacts with foreign firms. Viewed from technical efficiency, however, Faruq and Yi (2010), using the Data Envelopment Analysis (DEA) technique to estimate the technical efficiency of firms in Ghana across six manufacturing industries during 1991-2002, observe that the characteristics of manufacturing firms in Ghana, viz., firm size, age, foreign ownership, and the mix of labor and capital used during the production process, are positively associated with firm efficiency. On his part however, Kolasa (2007) examines the existence of externalities associated with FDI in a host country using firm level panel data for the Polish corporate sector and finds that while domestic firms benefit from foreign presence in the same industry and in downstream industries, the absorptive capacity of domestic firms is highly relevant to the size of spillovers. Aysa (2011) evaluates the latter argument in the analysis of the horizontal productivity spillover effects of foreign ownership on Turkish firms by employing a panel of 215 firms over the period 2004-2008. The study findings however reveal that although domestic firms benefit from the productivity spillovers from foreign-owned firms, absorptive capacity does not matter for productivity spillover benefits. Instead, Sinani and Meyer (2004), who emp loy a panel data technique in Estonia for the period 1994-1999 to study technology transfers from FDI, argue that the magnitude of the spillover effect depend on the domestic firm's size, its ownership structure and trade orientation.

With regard to origin, Monastiriotis \& Borrell (2013), using firm-level data from the Business Environment and Enterprise Performance Survey (BEEPS) covering 28 transition countries over the period 2002-2009, estimate the direct and intra-industry productivity effects of foreign ownership and examine how these differ across regional blocks, viz, Central and Eastern Europe (CEE), South and Eastern Europe (SEE), and, European Neighborhood Policy (ENP), according to the origin of the foreign investor (European Union -EU versus non-EU), across geographical scales (pure industry versus regional spillovers) and for different types of locations (capital-city regions versus the rest). Their results suggest that FDI of EU origin plays a distinctive role in the countries concerned by raising domestic productivity significantly more than investments from outside the EU.

Overall, the empirical evidence on the productivity spill-overs is mixed, with some studies suggesting positive spill-overs effects while others either find negative effects or no spill-overs at all. The characteristics of firms and Heterogeneity appear to play a key role in explaining these differences. A country analysis is therefore a more prudent approach than a cross-country assessment and is therefore preferred in the current study to avoid irrelevant policies. The quantification of the spillover effects is still a missing link for the case of Uganda. We focus on the horizontal spillovers in intra-industry to shed light into the association between labor productivity and firm characteristics. Moreover issues regarding the location of the firm, profits, and an analysis to capture the ownership and sector-wide effects of spillovers, in addition to the interactive effect of the traditional variables in the labor productivity model such as capital intensity, technology gap, firm size and profit, appear to have escaped the attention of many previous studies. We contribute to literature by taking all these missing links into consideration. An additional novelty in the current analysis is the evaluation of the role of firms orig inating from OECD countries vis-a-v is other regions, particularly Asia. Specifically, from which foreign investors (by 
origin) do domestic manufacturing firms in Uganda gain most? We equally endeavor to provide quantitative evidence to this informative question.

\section{Econometric Es timation}

\subsection{Model Specification for Spillover Effects of FDI}

Empirical studies investigating the technological spillovers from FDI to domestic firms have either used total factor productivity (TFP) or labor productivity as dependent variables. Since our interest is to isolate the effects of increased capital intensity on labor productivity and to compare our results with previous studies that examine the impact of FDI on the domestic firms using the same measure (e.g. Jordaan, 2008, and, Mebratie and Bedi, 2013), labor productivity is preferred to total factor productivity or any other alternative measures.

The model starts by assuming a Cobb-Douglas production function:

$$
Y=A K^{\alpha} L^{\beta}
$$

where Y stands for output; A stands for the efficiency parameter; $\mathrm{K}$ and $\mathrm{L}$ represents the factor inputs used in the production process (capital and labor, respectively) while $\alpha$ and $\beta$ denote the elasticity of capital and labor inputs, respectively. Assuming there are constant returns to scale, such that

$$
\alpha+\beta=1
$$

Following Jordaan (2008), we assume the possibility of not only constant returns but also increasing returns or decreasing returns, implying that equation (2a) can now be expressed as

$$
\alpha+\beta=\delta,
$$

where $\delta$ can be smaller, equal or greater than 1 . Th is is the same as $\beta=\delta-\alpha$.

Equation 2(b) can like wise be expressed as:

$$
\beta-1=\delta-\alpha-1 .
$$

Substituting expression 2(c) in (1) we get:

$$
Y=A K^{\alpha} L^{\delta-\alpha-1}
$$

We then divide both sides by L to obtain a production function in its intensive form as:

$$
\frac{Y}{L}=A\left(\frac{K}{L}\right)^{\alpha} L^{\delta-1}
$$

Suppose we include the firms (i) and time (t ) element in equation (4) and then take the natural logarith ms on both sides, we obtain a linear function given by:

$$
\log \left(\frac{Y_{i t}}{L_{i t}}\right)=\log \left(A_{i t}\right)+\alpha \log \left(\frac{K_{i t}}{L_{i t}}\right)+(\delta-1) \log L_{i t}+\varepsilon_{i t}
$$

Equation (5) contains a parameter $(\delta-1)$ that is unknown; we use this parameter to construct a proxy to control for scale economies that is used in our specified model; the variable is included to control for increasing returns to scale. Hence we can say that labor productivity depends on the productivity efficiency (A), which is a constant, capital intensity (KI), labor quality (LQ), firm size (SIZE) and foreign presence (HORI). Therefore our preferred model is specified as:

$$
\begin{gathered}
L P_{i t}=\beta_{0}+\beta_{1} K I_{i t}+\beta_{2} \operatorname{SIZE}_{i t}+\beta_{3} L Q_{i t}+\beta_{4} \operatorname{HORI}_{i t}+\alpha_{i} \sum_{i=1}^{n} X_{i t}+\varepsilon_{i t} \\
\varepsilon=\mu_{i t}+v_{i t} ; i=1, \ldots, N \text { and } t=1, \ldots, T
\end{gathered}
$$

In this case,

$L P_{i t}$ stands for $\left(\frac{Y}{L}\right)_{i t} ; K I_{i t}$ and $S I Z E_{i t}$ stand for $\left(\frac{K}{L}\right)_{i t}$ and $(\delta-1) L_{i t}$, respectively. 
Here LP is domestic labor productivity, $\varepsilon_{i}$ stands for the error term for the ith firm, $u$ is the unknown individual firm effects, $v$ error term with zero mean and constant variance. $\beta$ stands for the coefficients to be estimated, $i$ is the firm while $t$ stands for time. All variables are measured in nominal terms and are estimated in $\log$ forms. We include additional variables, $\mathrm{X}$, which may affect labor productivity. These include exports, imports, profits and technology gap. However, we leave out the first two due to data constraints.

In order to find out whether the spillover effects depend on the size of foreign firms, capital intensity or technological gap, we introduce interaction terms as follows:

In the presence of firm size (SIZE):

$$
L P_{i t}=\beta_{0}+\beta_{1} K I_{i t}+\beta_{2} S_{I Z E_{i t}}+\beta_{3} L Q_{i t}+\beta_{4} T G_{i t}+\beta_{5} \text { profit }_{i t}+\beta_{6} H_{O R I}+\beta_{7} H O R I * S I Z E+\varepsilon_{i t}
$$

Then the marginal effect is equivalent to:

$$
\frac{\partial L P_{i t}}{\partial H O R I_{i t}}=\beta_{6}+\beta_{7} S I Z E_{i t}
$$

In the presence of capital intensity (KI):

$$
L P_{i t}=\beta_{0}+\beta_{1} K I_{i t}+\beta_{2} S I Z E_{i t}+\beta_{3} L Q_{i t}+\beta_{4} T G_{i t}+\beta_{5} \text { profit }_{i t}+\beta_{6} H O R I_{i t}+\beta_{8} H O R I * K I_{i t}+\varepsilon_{i t}
$$

The marginal impact in this case will be:

$$
\frac{\partial L P_{i t}}{\partial H O R I_{i t}}=\beta_{6}+\beta_{8} K I_{i t}
$$

In case of technology gap (TG):

$$
L P_{i t}=\beta_{0}+\beta_{1} K I_{i t}+\beta_{2} S_{I Z E_{i t}}+\beta_{3} L Q_{i t}+\beta_{4} T G_{i t}+\beta_{5} \text { profit }_{i t}+\beta_{6} H O R I_{i t}+\beta_{9} H O R I * T G_{i t}+\varepsilon_{i t}
$$

By implication,

$$
\frac{\partial L P_{i t}}{\partial H O R I_{i t}}=\beta_{6}+\beta_{9} T G_{i t}
$$

With regard to profit:

$$
L P_{i t}=\beta_{0}+\beta_{1} K I_{i t}+\beta_{2} S_{Z I Z E_{i t}}+\beta_{3} L Q_{i t}+\beta_{4} T G_{i t}+\beta_{5} \text { profit }_{i t}+\beta_{6} H O R I_{i t}+\beta_{10} H O R I * \text { profit }_{i t}+\varepsilon_{i t}
$$

The corresponding marg inal impact is then:

$$
\frac{\partial L P_{i t}}{\partial H O R I_{i t}}=\beta_{6}+\beta_{10} \text { profit }_{i t}
$$

The study employs fixed effects approach. However we also run regressions using the alternative random effects and pooled OLS, but due to space the results therefrom are not presented since they appear not to be significantly different from those of the FE estimator and are available on request.

\subsection{Definition and Measurement of the Variables}

The dependent variable is labor productivity (LP) measured as the ratio of the firm level turnover (Y) to the total number of employees (L) in the Ugandan manufacturing sector; $\mathrm{L}$ is divided into skilled and unskilled. The independent variables of interest include capital intensity (KI - measured as the ratio of fixed assets $(\mathrm{K})$ to the number of employees in each firm), labor quality (LQ - measured as ratio of skilled to unskilled labor), firm size (SIZE - the ratio of the firm output to output for the largest firm in each sector), technology gap (TG - the ratio of average productivity of the foreign firm to the average productivity of the domestic firm in the same industry), profits and spillovers (HORI). A positive sign of the coefficient of LQ is expected and contributes to an increase in labor productivity. The size of the TG might be positively (learning potential) or negatively (learning difficulty) related to spillovers. We also expect positive signs on the KI and SIZE coefficients. We capture the impact of foreign presence on domestic firms in the same industry (spillover effects) using HORI measured by the share of foreign emp loy ment to total industry employment (as in Blomström et al. 2000). It is however difficult to state a priori the direction of the impact of foreign presence as implied in theory. Table 3 displays the descriptive statistics and the pairwise correlation matrix of the variables. 
Table 3. Descriptive statistics and pairwise correlation matrix

\begin{tabular}{|c|c|c|c|c|c|c|c|c|c|c|c|}
\hline & \multicolumn{5}{|c|}{ Descriptive Statistics } & \multicolumn{6}{|c|}{ Pairwise correlation Matrix } \\
\hline & Mean & Std. Dev. & Min & $\operatorname{Max}$ & Obs & $\mathrm{KI}$ & Lbr_qlty & SIZE & HORI & TG & profit \\
\hline KI & -1.90821 & 2.042804 & -15.0389 & 5.082956 & 780 & 1 & & & & & \\
\hline Lbr_qlty & -0.32989 & 0.270641 & -1.94591 & 0.054067 & 1004 & -0.036 & 1 & & & & \\
\hline SIZE & -4.02337 & 2.455319 & -13.9027 & 5.69E- 08 & 858 & -0.3775 & 0.0363 & 1 & & & \\
\hline HORI & -1.35299 & 0.523976 & -3.16407 & -0.28768 & 713 & 0.0337 & 0.4341 & -0.0524 & 1 & & \\
\hline TG & -4.07312 & 2.589933 & -10.9706 & 2.266709 & 620 & -0.407 & -0.2171 & 0.7698 & -0.4208 & 1 & \\
\hline profit & 11.50296 & 2.218307 & 4.828113 & 16.91122 & 493 & -0.0507 & -0.0625 & 0.6114 & -0.175 & 0.7614 & 1 \\
\hline
\end{tabular}

Source: Author's calcu lations based on PSIS data

\subsection{Data Source and Estimation Methods}

The firm level data used in this study was obtained from the annual Private Sector Investment Survey (PSIS) jointly conducted by the Bank of Uganda (BOU) and the Uganda Investment Authority (UIA). It is the best detailed dataset available covering the period of four years (2007-2010) for Ugandan manufacturing firms. The objectives of the surveys are: (i) to enrich and update the national database with vital information on private entities to guide planning and policy ((ii) to identify gaps to facilitate provision of better services that may attract more foreign investors and (iii) to assess the investment promotion strategy effectiveness and the investment climate in Uganda (see, private sector investment survey 2011). The data set contains information on location by region, ownership either foreign or do mestic, employment levels and type or characteristics of the emp loyees (i.e. both skilled and unskilled labor), value of fixed assets, total output (proxied by turnover) and industries. The key piece of information provided in the data is the ownership of firms. Specifically, ownership is divided into two: domestic and foreign ownership and we use this information to construct the horizont al spillovers. A summary of the data by subsector, orig in, location and ownership is presented in Table 4 to augment Table 2. 
Table 4 Manufacturing sector in Uganda by subsector, origin of FDI, location and ownership - 2007-2010

\begin{tabular}{|c|c|c|c|c|c|c|c|c|c|c|c|c|c|c|c|}
\hline \multirow[b]{2}{*}{ Sub-Sector } & \multicolumn{6}{|c|}{ Origin } & \multicolumn{3}{|c|}{ Location } & \multicolumn{6}{|c|}{ Ownership } \\
\hline & OECD & Asia & Africa & $\mathrm{CA}$ & Uganda & Unknown & Central & East & West & $\mathrm{JV}$ & JVF & JVL & WF & WL & Total \\
\hline $\begin{array}{l}\text { Chemical and } \\
\text { chemical }\end{array}$ & 0 & 4 & 12 & 0 & 20 & 0 & 36 & 0 & 0 & 4 & 12 & 0 & 0 & 20 & 36 \\
\hline $\begin{array}{l}\text { Cotton and } \\
\text { Textiles }\end{array}$ & 4 & 4 & 4 & 0 & 32 & 0 & 40 & 4 & 0 & 0 & 0 & 8 & 12 & 24 & 44 \\
\hline Edible Oil & 0 & 0 & 0 & 0 & 12 & 0 & 12 & 0 & 0 & 0 & 0 & 0 & 0 & 12 & 12 \\
\hline $\begin{array}{l}\text { Fabricated } \\
\text { metal prod }\end{array}$ & 8 & 12 & 20 & 0 & 28 & 0 & 48 & 8 & 12 & 4 & 12 & 4 & 24 & 24 & 68 \\
\hline $\begin{array}{l}\text { Food products } \\
\text { and beverages }\end{array}$ & 20 & 40 & 44 & 4 & 116 & 0 & 176 & 24 & 24 & 12 & 44 & 4 & 52 & 112 & 224 \\
\hline Furniture & 4 & 0 & 0 & 0 & 12 & 4 & 20 & 0 & 0 & 0 & 0 & 0 & 4 & 16 & 20 \\
\hline $\begin{array}{l}\text { Leather and } \\
\text { related } p\end{array}$ & 0 & 0 & 0 & 0 & 16 & 0 & 16 & 0 & 0 & 0 & 0 & 0 & 0 & 16 & 16 \\
\hline $\begin{array}{l}\text { Machinery and } \\
\text { equipment }\end{array}$ & 8 & 0 & 0 & 0 & 0 & 0 & 8 & 0 & 0 & 4 & 4 & 0 & 0 & 0 & 8 \\
\hline $\begin{array}{l}\text { Manufacture of } \\
\text { paints }\end{array}$ & 0 & 0 & 0 & 0 & 12 & 0 & 12 & 0 & 0 & 0 & 0 & 0 & 0 & 12 & 12 \\
\hline $\begin{array}{l}\text { Metal and metal } \\
\text { products }\end{array}$ & 8 & 0 & 4 & 0 & 48 & 0 & 40 & 8 & 12 & 4 & 0 & 4 & 8 & 44 & 60 \\
\hline $\begin{array}{l}\text { Other Che mical } \\
\text { Products }\end{array}$ & 0 & 4 & 0 & 0 & 0 & 0 & 4 & 0 & 0 & 0 & 4 & 0 & 0 & 0 & 4 \\
\hline $\begin{array}{l}\text { Other } \\
\text { manufacturing }\end{array}$ & 32 & 8 & 8 & 0 & 92 & 0 & 116 & 20 & 4 & 4 & 20 & 28 & 16 & 72 & 140 \\
\hline $\begin{array}{l}\text { Other } \\
\text { non-metallic mi }\end{array}$ & 4 & 0 & 0 & 0 & 20 & 0 & 24 & 0 & 0 & 0 & 0 & 0 & 4 & 20 & 24 \\
\hline $\begin{array}{l}\text { Other transport } \\
\text { equip }\end{array}$ & 4 & 0 & 0 & 0 & 0 & 0 & 4 & 0 & 0 & 0 & 0 & 0 & 4 & 0 & 4 \\
\hline $\begin{array}{l}\text { Paper and paper } \\
\text { products }\end{array}$ & 4 & 0 & 12 & 0 & 44 & 0 & 52 & 8 & 0 & 4 & 0 & 8 & 12 & 36 & 60 \\
\hline Pharmaceuticals & 12 & 16 & 12 & 0 & 20 & 0 & 56 & 4 & 0 & 12 & 8 & 4 & 20 & 16 & 60 \\
\hline $\begin{array}{l}\text { Printing and } \\
\text { media record }\end{array}$ & 0 & 4 & 0 & 0 & 28 & 0 & 28 & 4 & 0 & 0 & 0 & 8 & 4 & 20 & 32 \\
\hline $\begin{array}{l}\text { Rubber and } \\
\text { plastic products }\end{array}$ & 16 & 0 & 12 & 0 & 72 & 0 & 96 & 4 & 0 & 4 & 8 & 20 & 16 & 52 & 100 \\
\hline $\begin{array}{l}\text { Tobacco } \\
\text { products }\end{array}$ & 4 & 4 & 0 & 0 & 8 & 0 & 16 & 0 & 0 & 0 & 8 & 0 & 0 & 8 & 16 \\
\hline $\begin{array}{l}\text { Wearing } \\
\text { apparel }\end{array}$ & 8 & 0 & 4 & 0 & 8 & 0 & 20 & 0 & 0 & 0 & 4 & 0 & 8 & 8 & 20 \\
\hline $\begin{array}{l}\text { Wood and of } \\
\text { products }\end{array}$ & 0 & 8 & 8 & 0 & 28 & 0 & 40 & 4 & 0 & 4 & 4 & 8 & 8 & 20 & 44 \\
\hline Total & 136 & 104 & 140 & 4 & 616 & 4 & 864 & 88 & 52 & 56 & 128 & 96 & 192 & 532 & 1,004 \\
\hline
\end{tabular}

Note: CA is Central Africa; JV is Joint Venture; JVF is Joint Venture Foreign; JVL is Joint Venture Local; WF is Wholly Foreign; WL is Wholly Local.

Source: Co mpiled from Private Sector Investment Survey data (see data section) 


\section{Estimation Results and Discussion}

The regression results are presented in Tables 5-7. The baseline model in Table 5, Specification (1), provides evidence pertaining to the main drivers of labor productivity in Uganda. To begin with, we find that the coefficient on HORI is negative (-0.791) and highly significant at $1 \%$ conventional level. By implication, foreign firms have negative direct effects on domestic firms, perhaps due to the possibility that the former may prevent the leakages of technology to the latter in the same industry. We purport an existence of learning difficulties of local firms from foreigners especially where the latter use complicated technology that may not easily be copied by the former. Such adverse competition effect that is induced by the entry of foreign-owned manufacturing firms is not uncommon in literature. A seminal work by Aitken \& Harrison, (1999) already alludes to the same just as the other recent studies done on the developing countries (e.g. Subash, 2006; Wald kirch and Ofosu, 2010). However, as noted earlier on, we purport in the current study that the observed impact of HORI is likely to depend on other characteristics (e.g. technology gap, capital intensity, labor skills and profit levels), location, ownership and origin of foreign investors. We come back to this issue later.

Another variable of interest is the firm size. Our results support the empirical evidence that the firm size is positively related to labor productivity. Looking at specification (1), the coefficient on SIZE is positive and statistically significant at $1 \%$ conventional level which means that a $1 \%$ increase in the firm size relative to the largest firm in the industry raises the productivity of domestic firms by $1.938 \%$. The observed relationship supports the hypothesis that the existence of scale economies leads to increased labor productivity. In other words, the larger the firm size, the more efficient the firm will be and the higher the productivity of domestic firms and vice versa other factors constant. In essence it is likely that as firms become larger in size, they may achieve greater cost efficiency due to economies of scale and product differentiation. Our finding is however similar to those of Liu (2002) and Bekes et al. (2006). The relevant coefficient on labor quality is similarly positive and highly significant at $1 \%$ statistical level. Indeed, a $1 \%$ increase in the quality of labor appears to reinforce productivity by about $0.6 \%$. By implication, labor quality plays a substantive role in explaining the differences in firm level productivity across the Ugandan manufacturing firms.

However, we observe that in Column (2), the direct effect of technology gap spillovers is negative and highly significant as the relevant coefficient testifies, imply ing an adverse impact of an increase in TG on productivity. Specifically, a $1 \%$ increases in the technological gap of foreign firms relative to domestic firms is found to reduce domestic labor productivity by $0.926 \%$. By implication, domestic firms could be lacking the necessary human capital and technological capabilities to access and benefit from foreign knowledge. The finding, though contrary to Wang and Blomström (1992) who finds evidence that a larger technology gap increases the scope for horizontal spillovers, is in line with more recent literature (e.g. Havranek and Irsova, 2011, Farole and Winkler, 2014) that emphasize the need to reduce the technology gap if positive spillover are to be realized.

On the other hand, we fail to find evidence that capital intensity matters for labor productivity. As exhibited in Colu mn (1), Table 5, the corresponding coefficient is negative and nowhere significant at any conventional level. The results suggest that capital accumulation continues to be an important factor in determining labor productivity. Other factors constant, if firms employed more capital per worker, labor productivity in the Ugandan manufacturing firms would increase and vice versa. Using specification 3, a $1 \%$ increases in capital intensity increases labor productivity by $0.56 \%$. The results obtained in this study are similar to those of Buckley et al. (2007), Le and Pomfret (2008) and Ludo et al. (2008). However, the effect of profits on labor productivity as presented in Column (1), Table 5, is remarkably robust in all specifications (1) to (5), showing on average a positive unique effect. Specifically, a $1 \%$ increase in the profits of the firm might increase labor product ivity by about 0.008 percentage points. This appears to be small in magnitude and indeed only weakly significant at $10 \%$ conventional level, but it conforms to the hypothesis that when a firm shares is profits with workers, there is a like lihood that labor productivity will increase. 
Table 5. Drivers of labor productivity - horizontal spillovers and interactions

\begin{tabular}{|c|c|c|c|c|c|}
\hline & (1) & $\begin{array}{c}(2) \\
\text { HORI_TG }\end{array}$ & $\begin{array}{c}(3) \\
\text { HORI_KI }\end{array}$ & $\begin{array}{c}(4) \\
\text { HORI_SIZE }\end{array}$ & $\begin{array}{c}(5) \\
\text { HORI_Profit }\end{array}$ \\
\hline \multirow[t]{2}{*}{ KI } & -0.000 & 0.001 & -0.024 & 0.001 & -0.000 \\
\hline & {$[0.003]$} & {$[0.003]$} & [0.034] & {$[0.003]$} & [0.003] \\
\hline \multirow[t]{2}{*}{ Lbr_qlty } & $0.600 * * *$ & $0.428 * *$ & $0.604 * * *$ & $0.512^{* * *}$ & $0.543^{* * *}$ \\
\hline & {$[0.201]$} & [0.192] & [0.196] & [0.193] & {$[0.200]$} \\
\hline \multirow[t]{2}{*}{ SIZE } & $1.938 * * *$ & $1.954 * * *$ & $1.929 * * *$ & $2.001 * * *$ & $1.948 * * *$ \\
\hline & [0.047] & {$[0.058]$} & {$[0.051]$} & {$[0.059]$} & {$[0.051]$} \\
\hline \multirow[t]{2}{*}{ HORI } & $-0.791 * * *$ & $-0.738 * * *$ & $-0.835^{* * *}$ & $-0.697 * * *$ & $-1.169 * * *$ \\
\hline & [0.098] & [0.108] & {$[0.081]$} & [0.105] & [0.149] \\
\hline \multirow[t]{2}{*}{ TG } & $-0.965 * * *$ & $-0.926 * * *$ & $-0.961 * * *$ & $-0.971 * * *$ & $-0.975 * * *$ \\
\hline & [0.043] & {$[0.060]$} & [0.043] & [0.048] & {$[0.047]$} \\
\hline \multirow[t]{2}{*}{ profit } & $0.008^{*}$ & $0.008^{*}$ & $0.008^{*}$ & $0.009^{* *}$ & $0.049 * * *$ \\
\hline & {$[0.004]$} & {$[0.004]$} & {$[0.004]$} & {$[0.004]$} & {$[0.014]$} \\
\hline \multirow[t]{2}{*}{ HORI_TG } & & $0.047 * * *$ & & & \\
\hline & & {$[0.018]$} & & & \\
\hline \multirow[t]{2}{*}{ HORI_KI } & & & -0.016 & & \\
\hline & & & [0.023] & & \\
\hline \multirow[t]{2}{*}{ HORI_SIZE } & & & & $0.045^{* *}$ & \\
\hline & & & & {$[0.020]$} & \\
\hline \multirow[t]{2}{*}{ HORI_prof } & & & & & $0.029 * * *$ \\
\hline & & & & & {$[0.010]$} \\
\hline Observations & 346 & 346 & 346 & 346 & 346 \\
\hline
\end{tabular}

Note: The dependent variable is LP in log form all explanatory variables are in log form; Robust standard errors in brackets; *** $\mathrm{p}<0.01, * * \mathrm{p}<0.05, * \mathrm{p}<0.1$

In Table 6 we provide additional direct effects regarding the spillovers on labor productivity by subsector of manufacturing (Columns 1-7) and by ownership (Columns 8-12). One outstanding result is that the pharmaceuticals subsector exhibits positive spillovers. While we take this outcome with a grain of salt given the few observations in the relevant subsample, there is a possibility of the learning potential with domestic firms positioned to gain from foreign firms. However, in the same subsector the larger the size of the firm the smaller the advantages accrued to it in terms of productivity. While it is recorded that capital intensity is inversely associated with productivity in the Pharmacy subsector, the Metal subsector appears to gain out of an increase in the same. Similarly Profit matters for the latter just as the opposite is true for the former. And while labor quality is significantly helpful in the Paper and Pharmacy subsectors, it is deleterious in the Rubber and Plastics subsectors. On the other hand, the same variable matters significantly for joint ventures that are predominantly foreign as opposed to any other type of ownership. A similar observation applies to profit. Specifically, a $1 \%$ increase in profit levels appears to increase labor productivity by about 0.018 percentage points. However, considering the same type of ownership, capital intensity appears to impact negatively on productivity, though the result is weakly significant and the coefficient magnitude small $(-0.008)$. There is no evidence for the other types of ownership regarding the effect of the same on labor productivity, even though the possibility of the positive influence in Joint Venture Local and in firms that are Wholly Foreign if we go by the economic sign is not dismissible. Overall, Joint Ventures have the potential to gain in labor productivity from an improvement in capital intensity, labor quality, profits and firm size. 
Table 6. Drivers of labor productivity - by sector and ownership

\begin{tabular}{|c|c|c|c|c|c|c|c|}
\hline & \multicolumn{7}{|c|}{ (a) Sector } \\
\hline & (1) & (2) & (3) & (4) & (5) & (6) & (7) \\
\hline & FOOD & METAL & PAPER & PHARMACY & RUBBER \& & FAB & OTHER \\
\hline & & & & & PLASTICS & METAL & MANUF \\
\hline \multirow[t]{2}{*}{ KI } & -0.001 & $0.067 * *$ & 0.013 & $-0.102 * * *$ & -0.002 & $-0.000 * *$ & -0.009 \\
\hline & [0.004] & {$[0.023]$} & [0.019] & [0.024] & {$[0.002]$} & {$[0.000]$} & [0.009] \\
\hline \multirow[t]{2}{*}{ Lbr_qlty } & 0.259 & 0.079 & $11.837 * * *$ & $6.276 * *$ & $-2.495 * * *$ & & -0.244 \\
\hline & {$[0.236]$} & [0.216] & [0.837] & [2.204] & [0.227] & & [0.170] \\
\hline \multirow[t]{2}{*}{ SIZE } & $1.855 * * *$ & $1.762 * * *$ & $1.471 * * *$ & $-3.990 * *$ & $2.451 * * *$ & $2.000 * * *$ & $1.908 * * *$ \\
\hline & [0.099] & [0.127] & [0.153] & [1.115] & [0.106] & {$[0.000]$} & {$[0.066]$} \\
\hline \multirow[t]{2}{*}{ HORI } & $-0.698 * * *$ & $-0.975 * * *$ & $-4.147 * * *$ & $5.407 * * *$ & $-1.348 * * *$ & -0.000 & $-0.857 * * *$ \\
\hline & [0.118] & [0.143] & [0.394] & [1.036] & [0.191] & {$[0.000]$} & [0.136] \\
\hline \multirow[t]{2}{*}{ TG } & $-0.909 * * *$ & $-0.919 * * *$ & $-0.425 * * *$ & $4.980 * * *$ & $-1.449 * * *$ & $-1.000 * * *$ & $-0.954 * * *$ \\
\hline & [0.077] & [0.076] & [0.119] & [1.089] & {$[0.105]$} & {$[0.000]$} & [0.053] \\
\hline \multirow[t]{2}{*}{ profit } & -0.001 & $0.037 * *$ & -0.003 & $-0.022 * * *$ & 0.004 & -0.000 & $0.013^{*}$ \\
\hline & [0.007] & {$[0.010]$} & [0.006] & [0.004] & [0.003] & {$[0.000]$} & [0.006] \\
\hline \multirow[t]{6}{*}{ Observations } & 88 & 19 & 27 & 14 & 49 & 30 & 44 \\
\hline & \multicolumn{5}{|c|}{ (b) Ownership } & & \\
\hline & (1) & (9) & $(10)$ & (11) & (12) & & \\
\hline & JOINT & JOINT & JOINT & WHOLLY & WHOLLY & & \\
\hline & & LOCAL & FOREIGN & LOCAL & FOREIGN & & \\
\hline & 0.012 & 0.008 & $-0.008 *$ & -0.009 & 0.001 & & \\
\hline \multirow[t]{2}{*}{ KI } & [0.016] & [0.024] & [0.004] & [0.019] & {$[0.003]$} & & \\
\hline & -0.848 & 0.038 & $0.841 * * *$ & 0.626 & -0.083 & & \\
\hline \multirow[t]{2}{*}{ Lbr_qlty } & [1.790] & [0.514] & {$[0.066]$} & [0.374] & [0.115] & & \\
\hline & $2.089 *$ & $1.999 * * *$ & $1.780 * * *$ & $2.061 * * *$ & $1.913 * * *$ & & \\
\hline \multirow[t]{2}{*}{ SIZE } & [1.089] & {$[0.057]$} & [0.105] & [0.084] & {$[0.063]$} & & \\
\hline & -1.008 & $-1.070 * * *$ & $-0.700 * * *$ & $-1.117 * * *$ & -0.356 & & \\
\hline \multirow[t]{2}{*}{ HORI } & [1.428] & {$[0.226]$} & [0.113] & {$[0.134]$} & {$[0.217]$} & & \\
\hline & -1.113 & $-0.989 * * *$ & $-0.830 * * *$ & $-1.076 * * *$ & $-0.948 * * *$ & & \\
\hline \multirow[t]{2}{*}{ TG } & [1.090] & [0.047] & [0.097] & [0.088] & [0.046] & & \\
\hline & 0.003 & -0.020 & $0.018 * *$ & 0.000 & 0.003 & & \\
\hline profit & [0.006] & [0.020] & [0.008] & [0.003] & [0.006] & & \\
\hline Observations & 23 & 53 & 76 & 102 & 92 & & \\
\hline
\end{tabular}

Note: The dependent variable is LP in log form all explanatory variables are in log form; Robust standard errors in brackets; *** $\mathrm{p}<0.01, * * \mathrm{p}<0.05, * \mathrm{p}<0.1$

Besides the direct effects of foreign firms on the Ugandan manufacturing sector, the study also examines indirect channels through which FDI may impact labor productivity of domestic firms. In Specification (2), Table 5, an interaction of foreign presence (HORI) with the technological gap (TG) provides evidence that as the technology gap increases by $1 \%$, the effect of horizontal spillovers on labor productivity increases by about 0.047 percentage points. Note that the total marg inal impact is -0.93 (i.e. $-0.738+0.047 *-4.07$ ), which could suggest that in the presence of large technology gaps, horizontal spillovers would negatively be associated with labor productivity. For, domestic firms in such an environment appear to have learning difficulties from foreign firms. 
The results obtained are similar to those of Savuth (2012).

In addition the study also examines the indirect impact of foreign presence (HORI) with capital intensity (KI) and the firm size (SIZE) as shown in Table 5, Specifications 3 and 4, respectively. The interaction between HORI and capital intensity (HORI*KI) reveals that the differences in capital between foreign firms and domestic firms did not have any influence on the productivity of domestic firms. On the other hand, the interaction of HORI with SIZE (HORI*SIZE), intended to examine whether domestic firms experience the scale economies, reveals, as shown in Column (4), that firms of a relatively larger size benefit better than smaller size firms in an industry with a strong presence of foreign firms. With a $1 \%$ increase in the foreign - firm presence, domestic firms' productivity, given a median level of firm size, reduces by 0.88 . This reduction is lower than when the median level of technology gap is under consideration but higher in cases where either capital intensity or profits are interacted with spillovers.

As previously indicated, the current study extends the analysis by investigating the hypothesis that the origin of the investor may play a particularly relevant role in the realization of horizontal spillovers in Uganda. Specifically we address ourselves to the following question: Do OECD-originating FDI have a productivity advantage over other regions in terms of spillovers to domestic firms in Uganda? In line with our prior expectation, the answer is in the affirmative: Foreign investors originating from OECD countries have a remarkably better contribution in terms of spillovers to the Ugandan domestic manufacturing firms, in comparis on to those originating from Asia or other parts of Africa. In fact, going by the results in Table 7, Column (4), it is visibly evident that when foreign investors are from OECD region, the unique effect of HORI on labor productivity is -0.561 (i.e. $-0.898+0.337(1)$ ) compared to a worse scenario when FDI is from Asia, and in the latter case the unique effect is -1.01 .

In a Table 7, Columns (1) to (3), we also present the locational advantage and disadvantage of firms in the spillover-productivity nexus. Though weakly significant at $10 \%$ statistical level, firms located in the Central region enjoy higher productivity resulting from horizontal spillovers. The relevant coefficient suggests that domestic firms' productivity, given the central region to be the location of firms, decreases by 0.76 if foreign firm presence increases by $1 \%$. On the other hand, the point estimates in Column (3) suggest that domestic firms' labor productivity, given that the manufacturing firms are located in the western region, reduces by 1.73 if foreign - firm presence increases by $1 \%$. The reduction is however lower if the firms are located in the Eastern region than in the west. 
Table 7. Productivity spillovers by location and origin of FDI

\begin{tabular}{|c|c|c|c|c|c|c|c|}
\hline & \multicolumn{3}{|c|}{ Location in Uganda } & \multicolumn{4}{|c|}{ Origin of FDI } \\
\hline & (1) & (2) & (3) & (4) & (5) & (6) & (7) \\
\hline & EAST & CENTRAL & WEST & OECD & ASIA & AFRICA & UGANDA \\
\hline \multirow[t]{2}{*}{ KI } & -0.000 & -0.000 & -0.002 & 0.001 & -0.000 & -0.001 & 0.001 \\
\hline & {$[0.003]$} & {$[0.003]$} & {$[0.003]$} & {$[0.003]$} & {$[0.003]$} & {$[0.003]$} & {$[0.003]$} \\
\hline \multirow[t]{2}{*}{ Lbr_qlty } & $0.595^{* * *}$ & $0.595^{* * *}$ & $0.527^{* *}$ & $0.382 * *$ & $0.563^{* * *}$ & $0.668 * * *$ & $0.522 * * *$ \\
\hline & {$[0.196]$} & {$[0.196]$} & {$[0.221]$} & {$[0.193]$} & {$[0.196]$} & {$[0.193]$} & {$[0.185]$} \\
\hline \multirow[t]{2}{*}{ SIZE } & $1.923 * * *$ & $1.923 * * *$ & $1.978 * * *$ & $1.934 * * *$ & $1.953 * * *$ & $1.974 * * *$ & $1.954 * * *$ \\
\hline & {$[0.044]$} & [0.044] & {$[0.056]$} & {$[0.045]$} & {$[0.049]$} & {$[0.049]$} & {$[0.046]$} \\
\hline \multirow[t]{2}{*}{ HORI } & $-0.763 * * *$ & $-1.178 * * *$ & $-0.853 * * *$ & $-0.898 * * *$ & $-0.767 * * *$ & $-0.879 * * *$ & $-0.707 * * *$ \\
\hline & [0.099] & {$[0.230]$} & {$[0.100]$} & {$[0.084]$} & {$[0.101]$} & {$[0.095]$} & {$[0.109]$} \\
\hline \multirow[t]{2}{*}{ TG } & $-0.953 * * *$ & $-0.953 * * *$ & $-0.986 * * *$ & $-0.959 * * *$ & $-0.980 * * *$ & $-0.996 * * *$ & $-0.974 * * *$ \\
\hline & [0.039] & [0.039] & {$[0.055]$} & {$[0.041]$} & {$[0.044]$} & {$[0.045]$} & {$[0.041]$} \\
\hline \multirow[t]{2}{*}{ profit } & $0.008^{* *}$ & $0.008^{* *}$ & & 0.001 & 0.007 & $0.010^{* *}$ & 0.006 \\
\hline & {$[0.004]$} & {$[0.004]$} & & {$[0.004]$} & {$[0.004]$} & {$[0.004]$} & {$[0.004]$} \\
\hline \multirow[t]{2}{*}{ HORI_EAST } & $-0.415^{*}$ & & & & & & \\
\hline & {$[0.234]$} & & & & & & \\
\hline \multirow[t]{2}{*}{ HORI_CENTRAL } & & $0.415^{*}$ & & & & & \\
\hline & & [0.234] & & & & & \\
\hline \multirow[t]{2}{*}{ HORI_WEST } & & & $-0.880 * * *$ & & & & \\
\hline & & & {$[0.082]$} & & & & \\
\hline \multirow[t]{2}{*}{ HORI_OECD } & & & & $0.337 * * *$ & & & \\
\hline & & & & {$[0.080]$} & & & \\
\hline \multirow[t]{2}{*}{ HORI_ASIA } & & & & & $-0.243 * * *$ & & \\
\hline & & & & & {$[0.072]$} & & \\
\hline \multirow[t]{2}{*}{ HORI_AFRICA } & & & & & & 0.283 & \\
\hline & & & & & & {$[0.227]$} & \\
\hline \multirow[t]{2}{*}{ HORI_UGANDA } & & & & & & & $-0.307 * * *$ \\
\hline & & & & & & & {$[0.100]$} \\
\hline Observations & 346 & 346 & 572 & 346 & 346 & 346 & 346 \\
\hline
\end{tabular}

Note: The dependent variable is LP in log form all explanatory variables are in log form; Robust standard errors in brackets; $* * * \mathrm{p}<0.01, * * \mathrm{p}<0.05, * \mathrm{p}<0.1$

\section{Concluding Remarks}

We investigate the drivers of labor productivity in the firms at the intra-industry level with focus on the spillover effects of FDI in the Ugandan manufacturing sector over the period 2007-2010. A plethora of remarkable conclusions that dominate our findings need attention. Over all, there are significant negative spillover effects for the domestic firms in Uganda. By location, these are more adverse in the west and east but better in the central region. In addition, the Uganda manufacturing firms appear to gain much more, in terms of spillovers, from OECD-originating FDI than from any other source. The productivity advantage of OECD -originating FDI over investments from other parts of the world in terms of generating less significant negative effects via productivity spillovers for domestic firms, would perhaps point to the technology superiority and other advantages possessed by OECD firms that local firms struggle to imitate with limited success compared to the often labeled "second-hand Asian technology" considered "inferior" and not attractive to copy. Hence, leading to a catalysis of the observed negative spillovers via the Asian/African-originating FDI. Additionally, while firm size, labor 
quality and profit positively affect labor productivity, and technology gap does not, we fail to find significant evidence on the influence of capital intensity. An interaction of each of these variables with spillovers provides novel information. For example, from the interaction of HORI with TG we conclude that there is learning difficulty of domestic firms from foreign firms.

Larger firms do benefit more from spillovers in industries where foreign firms have a larger presence. However, the study also reveals that profits contribute positively to the relationship between spillovers and the domestic labor productivity in the Ugandan manufacturing sector. The aforementioned findings reflect the need for well-designed macroeconomic and industrial policies to attract FDI inflows and to improve the competitiveness of local firms. Since larger domestic firms benefit more from spillovers in industries where foreign firms have a larger presence, domestic firms in Uganda should also be given the same incentives as those given to foreign firms to encourage fair competition. Moreover, the finding of the locational advantage of the central region in terms of lesser negative spillovers might be a reflection of the need for improved infrastructure and other investor-friendly environ ment in the east and western parts of Uganda to attract foreign investors to these regions. Finally, our results suggest that the joint ventures (foreign) should be promoted if the manufacturing sector in Uganda is to reap not only from labor quality, firm size and profit spillovers, but also such an arrangement is likely to lead to less negative horizontal spillovers. Policies to steer collaboration between domestic and foreign firms in the manufacturing sector such as via trade fairs or advertising or patents would likely improve on the demonstration or imitation channel of horizontal spillovers. But it is also likely that foreign investors offer not only higher quality but also low-priced goods, leading to a shift of demand away from domestic products and forcing local firms to produce at lower, less efficient capacity level, which in itself makes competition translate into domestic productivity losses as it has a crowding - out or market - stealing effect (Aitken and Harrison 1999; Pfeiffer et al., 2014). In this case, policies designed to engineer fair competition and support an upgrade system of domestic firms still holed up in ancient inefficient technology due to institutional weaknesses deserve particular attention. Programs in line with skill acquisition through job training and the review of the curriculum to focus on labor quality would be a strategy in the right direction. But there is also need, in our view, to change the biased mentality of domestic firms that whatever is "Asian/African/Ugandan" in terms of technology is "inferior", as this is likely to deter learning and imitation for purposes of productivity improvement. Perhaps trade fairs, mass sensitization, advertisement and patent, that are inclusive of both domestic and foreign firms could be proper avenues via which better outcomes could be achieved.

While in the above analysis focuses on the drivers of labor productivity, several questions emerge in the course of investigation but need a separate study. For example, future micro studies would delve deeper into what in turn drives the contribution of foreign investors in the productivity-spillover analysis. Such an analysis is however likely to be limited by data. A comparative analysis involving all the east African countries would in addition provide a better picture on the catalysts of productivity; this is another area for future study. We also leave for further research an inter-industry analysis once data is available.

\section{Acknowledgments}

The authors wish to thank Professor Dr. Michael Landesmann and Professor Dr. Joseph Francois of Johannes Kepler University Lin z for the valuable professional comments. Sincere appreciations also go to anonymous reviewers of for their suggestions

\section{References}

African Development Bank. (2014). Annual Report. Tunis: AfDB. Retrieved from http://www.afdb.org/filead min/uploads/afdb

Aiken, B., \& Harrison, A. (1999). Do Domestic Firms Benefit from Direct Foreign Investment? Evidence from Venezuela. The American Economic Review, 89(3), 605-618. http://dx.doi.org/10.1257/aer.89.3.605

Aitken, B., Hanson, G. H., \& Harrison, A. (1997). Spillovers, Foreign Investment and Export Behavior. Journal of International Economics, 43(1-2), 103-132. http://dx.doi.org/10.1016/S0022-1996(96)01464-X

Annika, B. (2006). FDI and Spillover Effects in The Indian Pharmaceutical Industry. School of Economics and Management Department of Economics, MA, Unpublished.

Aysa, I. E. (2011). Foreign Direct Investment and Productivity Spillovers: Evidence from Turkey. Journal of Applied Finance and Banking, 1(4), 185-199.

Bekes, G., Kleinert, J., \& Toubal, F. (2006). Spillovers from Multinationals to Heterogeneous Domestic Firms: Evidence from Hungary. Discussion Papers No. DP 2006/16, Institute of Economics, Hungarian Academy of Sciences, Budapest. 
Bitzer, J., \& Gorg, H. (2008). Foreign Direct Investment, Competition and Industry Performance. Kiel Institute for the World Economy Working Paper, No. 1416.

Blomström, M., Kokko, A., \& Zejan, M. (2000). Foreign Direct Investment, Firm and Host Country Strategies. London: Macmillan.

Buckley, P. J., Clegg, L. J., Cross, A. R., Liu, X., Voss, H., \& Zheng, P. (2007). The determinants of Chinese outward foreign direct investment. Journal of International Business Studies, 38(4), 499-518. http://dx.doi.org/10.1057/palgrave.jibs.8400277

Bwalya, S. M. (2006). Foreign Direct Investment and Technology Spillovers: Evidence from Panel Data Analysis of Manufacturing Firms in Zambia, Journal of Development Economics, 81(2), 514-526. http://dx.doi.org/10.1016/j.jdeveco.2005.06.011

Chang-Tai, H. (2006). Do Domestic Chinese Firms Benefit from Foreign Direct Investment? International Center for Study of East Asian Development, Kitakyushu Working Paper Series, No. 30.

De Backer, K., \& Sleuwaegen, L. (2003). Does Foreign Direct Investment Crowd Out Domestic Entrepreneurship? Review of Industrial Organization, 22(1), 67-84. http://dx.doi.org/10.1023/A:1022180317898

Farole, T., \& Winkler, D. (2014). Making Foreign Direct Investment Work for Sub - Saharan Africa - Local Spillovers and Competitiveness in Global Value Chains," World Bank, Washington, DC.

Farouq, H. A., \& Yi, D. T. (2010). The Determinants of Technical Efficiency of Manufacturing Firms in Ghana. Global Economy Journal, 10(3), 1-21. http://dx.doi.org/10.2202/1524-5861.1646

Galeotti, E. (2009). Do Domestic Firms Benefit from Geographic Proximity with Foreign Investors? Evidence from the Privatization of the Czech Glass Industry. AUCO Czech Economic Review, 3(1), 26-47.

Gorg, H., \& Strobl, E. (2005). Spillovers from Foreign Firms through Worker Mobility: An Empirical $\begin{array}{llll}\text { Investigation. Scandinavian Journal of Economics, } & \text { 107(4), }\end{array}$ http://dx.doi.org/10.1111/j.1467-9442.2005.00427.x

Gorodnichenko, Y., Svejnar, J., \& Terrell, K. (2007). When Does FDI Have Positive Spillovers? Evidence from 17 Emerg ing Market Economies. Centre for Economic Policy Research, London, CEPR Discussion Paper, No. 6546.

Haddad, M., \& Harrison, A. (1993). Are there Positive Spillovers from Foreign Direct Investment? Evidence fro $m$ Panel Data for Morocco. Journal of Development Studies, 42(1), 51-74.

Havránek, T., \& Iršová, Z. (2011). Determinants of Horizontal Spillovers from FDI: Evidence from a Large Meta-Analysis. Czech National Bank (CNB) Working Paper Series, No. 7. Retrieved from http://www.cnb.cz/en/research/research_publications/cnb_wp/download/cnbwp_2011_07.pdf

Javorcik, B. S. (2004). Does Foreign Direct Investment Increase the Productivity of Domestic Firms? In Search of Spillovers through Backward Linkages. American Economic Review, 93(3), 605-627. http://dx.doi.org/10.1257/0002828041464605

Jordaan, J. (2008). Intra- and Inter-Industry Externalities from Foreign Direct Investment in Mexican Manufacturing Sector: New Evidence from Mexican Regions. World Development, 36(12), 2828-2854. http://dx.doi.org/10.1016/j. worlddev.2008.02.006

Karbasi, A., Ebrahim, M., \& Ghofrani, S. (2000). Impact of Foreign Direct Investment and Trade on Economic Growth. A Paper Presented at the Economic Research Foru m, 12th Annual Conference, 19th-21st December, Grand Hyatt, Cairo, Egypt.

Kathuria, V. (2001). Foreign Firms, Technology Transfer and Knowledge Spillovers to Indian Manufacturing Firms: A Stochastic Frontier Analysis. Applied Economics, 33(5), 625-42. http://dx.doi.org/10.1080/00036840121940

Kolasa, M. (2007). How Does FDI Inflow Affect Productivity of Domestic Firms? The Role of Horizontal and Vertical Spillovers, Absorptive Capacity and Competition. National Bank of Poland, Working Paper, No. 42. http://dx.doi.org/10.2139/ssrn.1118766

Konings J. (2001). The Effects of Foreign Direct Investment on Domestic Firms: Evidence from Firm-Level Panel Data in Emerging Economies. Economics of Transition, 9(3), 619-633. http://dx.doi.org/10.1111/1468-0351.00091

Le, Q. H., \& Pomfret, R. (2008). “Technology Spillovers from Foreign Direct Investment in Vietnam: Horizontal 
or Vertical Spillovers. Vietnam Development Forum (VDF), Working Paper, No. 85.

Liu, Z. (2002). FDI and Technology Spillovers: Evidence from China. Journal of International of Comparative Economics, 30(3), 579-602. http://dx.doi.org/10.1006/jcec.2002.1789

Ludo, C., Reth S., Plas mans, J., \& Bulcke, D. V. (2008). Productivity Spillovers from Foreign Direct Investment in the Cambodian Manufacturing Sector: Evidence from Establishment Level Data. Research Paper, No. 4.

Marcella, N., \& Resmini, L. (2010). Which Firms Create Them and Which Firms Really Benefit? Foreign Direct Investment Spillovers in New EU Member States. Economics of Transition, 18(3), 487-511.

Mebratie, A. D., \& Bedi, A. S. (2013). Foreign Direct Investment, Black Economic Empowerment and Labor Productivity in South Africa. Journal of International Trade and Economic Development, 22(1), 94-115. http://dx.doi.org/10.1080/09638199.2013.745287

Monastiriotis, V., \& Borrell, M. (2013). Origin of FDI and domestic productivity spillovers: does European FDI have a 'productivity advantage' in the ENP countries? Working Paper, 2/13 European Institute, London School of Economics.

Mutenyo, J., Opolot, J., \& Kalio, A. (2008). Determinants of Foreign Direct Investment: New evidence from Sub-Saharan Africa. Research Department, Bank of Uganda.

Nguyen, L. P. (2008). Productivity Spillovers from Foreign Direct Investment: Evidence from Vietnamese Firm Data, School of Commerce University of South Australia.

Obwona, M. B. (2001). Determinants of FDI and their Impact on Economic Growth in Uganda. African Development Review, 13(1), 46-81. http://dx.doi.org/10.1111/1467-8268.00030

Pfeiffer, B., Görg, H., \& Perez - Villar, L. (2014). The Heterogeneity of FDI in Sub - Saharan Africa. GIGA Working Papers WP 262/2014.

Ping, L., Liu, Z., \& Zhang, Y. (2009). Do Chinese Domestic Firms Benefit from Foreign Direct Investment Inflows? Evidence of Horizontal and Vertical Spillovers. China Economic Review, 20(4), 677-691. http://dx.doi.org/10.1016/j.chieco.2009.05.010

Ruane, F., \& Ugur, A. (2004). Foreign Direct Investment and Productivity Spillovers in Irish Manufacturing Industry: Evidence from Plant Level Panel Data. International Journal of the Economics of Business, 11(3), 53-66.

Savuth, C. (2012). Foreign Direct Investment and Productivity Spillovers: Empirical Evidence from Cambodia. Economics Bulletin, 32(3), 2015-2025.

Sinani, E., \& Meyer, K. E. (2004). Spillovers from Technology Transfer: The Case of Estonia. Journal of Comparative Economics, 32(3), 445-66. http://dx.doi.org/10.1016/j.jce.2004.03.002

Subash, S. (2006). Foreign Direct Investment and Technology Spillovers: Evidence from the Indian Manufacturing Sector. United Nations University Working Paper, No. 10.

UBOS. (2014). Uganda National Household Survey 2012/13. Kampala: Uganda Bureau of Statistics.

UNCTAD. (2010). World Investment Report 2010: Investing in a Low-Carbon Economy. United Nations Publications, Geneva, Switzerland.

UNCTAD. (2015). World Investment Report 2015: Reforming International Investment Governance. United Nations Publications, Geneva, Switzerland.

Vahter, P. (2004). The Effect of Foreign Direct Investment on Labor Productivity: Evidence from Estonia and Slovenia. University of Tartu Economics and Business Admin istration Working Paper, No. 32, November.

Waldkirch, A., \& Ofosu, A. (2010). Foreign Presence, Spillovers, and Productivity: Evidence from Ghana. World Development, 38(8), 1114-1126. http://dx.doi.org/10.1016/j.worlddev.2009.12.020

World Bank, (2004). Competing in the Global Economy: An Investment Climate Assessment of Uganda. Africa Private Sector Group (May). Washington: World Bank.

\section{Copyrights}

Copyright for this article is retained by the author(s), with first publication rights granted to the journal.

This is an open-access article distributed under the terms and conditions of the Creative Commons Attribution license (http://creativecommons.org/licenses/by/4.0/). 